\title{
Response of Potato as Influenced by Date of Sowing, Variety and Fertilizer Dose and its Influence on Succeeding Groundnut Crop
}

\author{
Th. Gangarani Devi* and Sunil Kumar Gunri \\ Department of Agronomy, Bidhan Chandra Krishi Viswavidyalaya, Mohanpur, \\ Nadia, West Bengal (741252), India \\ *Corresponding author
}

\section{Keywords}

Potato, Date of sowing, Variety, Fertilizer dose

Article Info

Accepted:

22 October 2019

Available Online:

10 November 2019

\section{A B S T R A C T}

An experiment was conducted at District seed farm of Bidhan Chandra Krishi Viswavidyalaya, Nadia, West Bengal in the year 2009-11 to study the effect of date of sowing, variety and fertilizer dose on Potato - groundnut cropping sequence in New Alluvial Zone of West Bengal. Varieties viz. Kufri Pukhraj $\left(\mathrm{V}_{1}\right)$, Kufri Chandramukhi $\left(\mathrm{V}_{2}\right)$ and Kufri Jyoti $\left(\mathrm{V}_{3}\right)$ were grown in two dates of sowings $\left(\mathrm{D}_{1}-18^{\text {th }}\right.$ November and $\mathrm{D}_{2}-$ $28^{\text {th }}$ November in both the year 2009 and 2010) with two fertilizer doses $\left(F_{1}-200: 150: 150\right.$ $\mathrm{kg} \mathrm{ha}^{-1}$ of $\mathrm{N}: \mathrm{P}_{2} \mathrm{O}_{5}: \mathrm{K}_{2} \mathrm{O}, \mathrm{F}_{2}-150: 125: 125 \mathrm{~kg} \mathrm{ha}^{-1}$ of $\mathrm{N}: \mathrm{P}_{2} \mathrm{O}_{5}: \mathrm{K}_{2} \mathrm{O}$ ). For the succeeding crop groundnut, 4 levels of fertilizer $\left(\mathrm{FG}_{1}\right.$ : No fertilizer, $\mathrm{FG}_{2:}: 25 \%$ of $\mathrm{RDF}, \mathrm{FG}_{3:} 50 \%$ of RDF, $\mathrm{FG}_{4:} 75 \%$ of RDF) doses were tested in the residual soil of potato. The experiment was laid out in split Strip plot design. The two years pooled data of potato in respect of plant stand $\mathrm{m}^{-2}$ at harvest, no. of tubers plant ${ }^{-1}$ and tuber weight plant ${ }^{-1}$ were found maximum when planting was done on November 18 . But higher single tuber weight was recorded when sowing was delayed till $28^{\text {th }}$ November. Date of sowing does not influenced significantly on tuber yield of various grades. "Kufri Pukhraj" recorded maximum numbers of tuber plant ${ }^{-1}$, higher single tuber weight and total tuber weight plant ${ }^{-1}$ and consequently the tuber yield. Application of fertilizer doses of 200:150:150 kg ha ${ }^{-1}$ of $\mathrm{N}$ : $\mathrm{P}_{2} \mathrm{O}_{5}: \mathrm{K}_{2} \mathrm{O}$ improved plant stand $\mathrm{m}^{-2}$ at harvest, no. of tuber plant ${ }^{-1}$ but they remain at par. However increased in fertilizer dose $\left(\mathrm{F}_{2}\right)$ leads to the increased in tuber weight plant ${ }^{-1}$ and also the total tuber yield significantly. Among the levels of fertilizer tested in groundnut, $\mathrm{FG}_{50}$ which received $50 \%$ of recommended dose of fertilizer proved to be the optimum doses of fertilizer as far as Pod yield ( $\mathrm{kg} / \mathrm{ha}$ ), haulm yield ( $\mathrm{kg} / \mathrm{ha})$ and kernel yield is concerned.

\section{Introduction}

Potato is one of the most important and widely cultivated crops of West Bengal. Date of sowing plays an important role in yield and yield attributes of potato. Delayed sowing reduces growing period, hastens maturity and ultimately reduces yield. Selection of suitable potato variety which is best suited for a particular date of sowing is very important to optimize the production. Nutrient requirement of potato is quiet high due to its high 
productive potentiality. Since potato is exhaustive feeder of nutrient, inclusion of legumes like groundnut become indispensible to maintain soil health. Groundnut, being a leguminous crop, can enrich soil by fixing atmospheric nitrogen. However studies on groundnut as a sequence crop of potato are very scanty. Hence, the present study was undertaken to find out the suitable nutrient management option for groundnut as well as potato using promising varieties under suitable sowing dates.

\section{Materials and Methods}

The field experiment was conducted at the District seed farm, 'AB' block at Bidhan Chandra Krishi Viswavidyalaya, Nadia, West Bengal during rabi season of 2009 and 2010. The farm is situated at $23.5^{0} \mathrm{~N}$ latitude and $89.0^{\circ} \mathrm{E}$ longitude with an average altitude of 9.75 meters above mean sea level. The experiment of the first crop was laid out in split plot design. The treatment consisted of two date of sowing $\left(\mathrm{D}_{1}-18^{\text {th }}\right.$ November and $\mathrm{D}_{2}-28^{\text {th }}$ November in both the year), three varieties $\left(\mathrm{V}_{1^{-}}\right.$Kufri Pukhraj, $\mathrm{V}_{2^{-}}$Kufri Chandramukhi, $\mathrm{V}_{3^{-}}$Kufri Jyoti) and two fertilizer doses $\left(\mathrm{F}_{1}-200: 150: 150 \mathrm{~kg} \mathrm{ha}^{-1}\right.$ of $\mathrm{N}$ : $\mathrm{P}_{2} \mathrm{O}_{5}: \mathrm{K}_{2} \mathrm{O}, \mathrm{F}_{2}-150: 125: 125 \mathrm{~kg} \mathrm{ha}^{-1}$ of $\mathrm{N}$ : $\mathrm{P}_{2} \mathrm{O}_{5}: \mathrm{K}_{2} \mathrm{O}$ ). Each treatment was replicated thrice. The fertilizer was applied according to the treatment dose and schedule. Full dose of $\mathrm{P}_{2} \mathrm{O}_{5}$ and $\mathrm{K}_{2} \mathrm{O}$ and half amount of $\mathrm{N}$ were applied as basal. The rest half of the $\mathrm{N}$ was top dressed at 30 days after planting. The variety Kufri Pukhraj was harvested 82 days after planting, Kufri Chandramukhi 106 days after planting and Kufri Jyoti 110 days after planting. For the succeeding crop groundnut, 4 levels of fertilizer $\left(\mathrm{FG}_{1}\right.$ : No fertilizer, $\mathrm{FG}_{2:} 25$ $\%$ of $\mathrm{RDF}, \mathrm{FG}_{3:} 50 \%$ of $\mathrm{RDF}, \mathrm{FG}_{4}$ and $75 \%$ of RDF) doses were tested in the residual soil of potato. Treatments of potato which received two fertilizer doses were again subdivided into four sub plots. In each sub-plot treatment, four levels of fertilizers were tried for groundnut as a succeeding crop. The experiment was laid out in split-strip plot design with three replications. FYM @ $5 \mathrm{t} \mathrm{ha}^{-1}$ was applied before planting.

\section{Results and Discussion}

\section{Effect on potato}

\section{Plant stand $\mathrm{m}^{-2}$}

Plant stand $\mathrm{m}^{-2}$ was not affected significantly with varied date of sowing, variety and also at varied levels of fertilizer. However, maximum (9.00) plant stand metre ${ }^{-2}$ was observed at $18^{\text {th }}$ November sowing. In case of variety, Kufri Jyoti shows maximum (9.10) plant stand metre $^{-2}$. Fertilizer dose of 200:150:150 kg ha of $\mathrm{N}: \mathrm{P}_{2} \mathrm{O}_{5}: \mathrm{K}_{2} \mathrm{O}$ shows máximum (8.90) plant stand metre ${ }^{-2}$ (Table 1 ).

\section{No. of tuber plant ${ }^{-1}$}

No. of tubers plant $^{-1}$ were affected significantly with varied date of sowing. It was found decreased with delaying of sowing dates. Highest no. of tuber plant ${ }^{-1}$ was observed at $18^{\text {th }}$ November sowing (5.23) while least was observed at $28^{\text {th }}$ November sowing (4.43) (Table 2). Similar observation was also reported by Sasani et al., 1981. Maximum number of tuber plant ${ }^{-1}$ (5.47) was recorded in Kufri Pukhraj followed by Kufri jyoti (4.55). Least value of 4.47 was recorded with Kufri Chandramukhi. Significant variation in number of tuber plant ${ }^{-1}$ was not observed with varied levels of fertilizers. However, maximum no. of tuber plant ${ }^{-1}$ (5.08) was registered when fertilizer was applied at the dose of 200:150:150 kg ha ${ }^{-1}$ of $\mathrm{N}: \mathrm{P}_{2} \mathrm{O}_{5}$ : $\mathrm{K}_{2} \mathrm{O}$.

\section{Single tuber weight}

Single tuber weight was not affected significantly with varied date of sowing. Sowing on $28^{\text {th }}$ November (52.14 g) produced 
highest single tuber weight. Kufri Pukhraj $(54.55 \mathrm{~g})$ yields maximum single tuber weight however it remains statistically at par with Kufri Chandramukhi (54.14 g). Single tuber weight did not vary significantly with varied levels of fertilizers.

\section{Tuber weight (g) plant ${ }^{-1}$}

Tuber weight plant $^{-1}$ were recorded highest when planting was done on $18^{\text {th }}$ November $(270.79 \mathrm{~g})$ than when planted on $28^{\text {th }}$ November (230.98 g) and they varied significantly. Among varietal treatments, Kufri Pukhraj (54.55 g) showed maximum tuber weight plant $^{-1}$ In case of fertilizer doses, tuber weight plant $^{-1}$ was reported higher when fertilizer was applied at the rate of 200:150:150 kg ha ${ }^{-1}$ of $\mathrm{N}: \mathrm{P}_{2} \mathrm{O}_{5}: \mathrm{K}_{2} \mathrm{O}(263.30$ g) than when applied with $150: 125: 125 \mathrm{~N}$ : $\mathrm{P}_{2} \mathrm{O}_{5}: \mathrm{K}_{2} \mathrm{O}(238.84 \mathrm{~g})$. The highest tuber weight plant $^{-1}$ (327.42 g) were found in the treatment combination of $18^{\text {th }}$ November sowing with Kufri Pukhraj under 200:150:150 $\mathrm{kg} \mathrm{ha}^{-1}$ of $\mathrm{N}: \mathrm{P}_{2} \mathrm{O}_{5}: \mathrm{K}_{2} \mathrm{O}$ dose of fertilizer.

\section{Tuber yield ( $\left.\mathrm{t} \mathrm{ha}^{-\mathbf{1}}\right)$}

Tuber yield of all grades and also the total yield did not show much difference with varied date of sowing. All of them remain at par in both the date of sowing. Tuber yield of both small and medium size were not significant in case of variety. However, for large size grade maximum yield of $5.47 \mathrm{t} \mathrm{ha}^{-1}$ was recorded in Kufri Pukhraj followed by Kufri Jyoti (3.05 $\left.\mathrm{t} \mathrm{ha}^{-1}\right)$ and Kufri Chandramukhi $\left(2.59 \mathrm{t} \mathrm{ha}^{-1}\right)$. Maximum total yield was obtained in Kufri Pukhraj (29.80 t $\mathrm{ha}^{-1}$ ). Similar findings have also been reported by Patel et al., 2002. Kufri Chandramukhi and Kufri Jyoti remain statistically at par. Tuber yield of small and large size grade did not vary significantly due to varied level of fertilizer. However, medium size tuber yield was significantly higher with 200:150:150 kg ha ${ }^{-1}$ of $\mathrm{N}: \mathrm{P}_{2} \mathrm{O}_{5}: \mathrm{K}_{2} \mathrm{O}\left(16.14 \mathrm{t} \mathrm{ha}^{-1}\right)$ than with lower dose $\left(14.25 \mathrm{t} \mathrm{ha}^{-1}\right)$. Consequently total tuber yield was higher significantly with higher dose of fertilizer $\left(27.79 \mathrm{t} \mathrm{ha}^{-1}\right)$.

The increase might be due to the positive effect of Nitrogen on growth and development and later on partitioning towards storage organs i,e tuber. Lanker et al., (2000) also reported the similar observation.

Available nitrogen, phosphorus, potassium $\left(\mathrm{kg} \mathrm{ha}^{-1}\right)$

Available NPK content of the soil varied significantly. Initial status of available $\mathrm{N}, \mathrm{P}$, and $\mathrm{K}$ of the soil was recorded before the planting and again after the harvest of the crop. A build up of soil available NPK was registered in all the treatments after harvesting. The maximum (235.11 kg ha $\left.{ }^{-1}\right)$ available Nitrogen and Phosphorus $(27.11 \mathrm{~kg}$ $\mathrm{ha}^{-1}$ ) in the soil was observed with first date of sowing of the variety Kufri Pukhraj under higher fertilizer levels. However, in case of available potassium, highest content was recorded when sowing was done on $18^{\text {th }}$ November using Kufri Jyoti under 200:150:150 kg ha ${ }^{-1}$ of $\mathrm{N}: \mathrm{P}_{2} \mathrm{O}_{5}: \mathrm{K}_{2} \mathrm{O}(240.51$ $\mathrm{kg} \mathrm{ha}^{-1}$ ) (Table 3).

\section{Effect on groundnut}

\section{Pod yield ( $\left.\mathrm{kg} \mathrm{ha}^{-1}\right)$}

Date of sowing and varietal treatment of preceding crop potato did not influence the pod yield of succeeding crop groundnut however fertilizer doses applied in potato produced significant effect in the succeeding crop groundnut. The highest pod yield was found in $\mathrm{F}_{1}$ (2604 $\mathrm{kg} \mathrm{ha} \mathrm{ha}^{-1}$ ) which was significantly superior to $\mathrm{F}_{2}\left(2479 \mathrm{~kg} \mathrm{ha}^{-1}\right)$ (Table 4). 


\begin{tabular}{|c|c|c|c|c|}
\hline \multicolumn{5}{|c|}{$\begin{array}{c}\text { Table.1 Effect of date of sowing, variety and fertilizer on plant } \mathrm{stand} / \mathrm{m}^{2} \text { at harvest and yield } \\
\text { attributing characters of potato }\end{array}$} \\
\hline Treatments & $\begin{array}{c}\text { Plant stand } \mathrm{m}^{-2} \text { at } \\
\text { harvest }\end{array}$ & $\begin{array}{l}\text { No. of tuber } \\
\text { plant }^{-1}\end{array}$ & $\begin{array}{l}\text { Single tuber weight } \\
(\mathrm{g})\end{array}$ & \multirow[t]{2}{*}{$\begin{array}{l}\text { Tuber weight }(\mathrm{g}) \\
\text { plant }^{-1}\end{array}$} \\
\hline & \multicolumn{3}{|c|}{ Date of sowing (D) } & \\
\hline$D_{1}$ & 9.00 & 5.23 & 51.72 & 270.79 \\
\hline $\mathbf{D}_{2}$ & 8.60 & 4.43 & 52.14 & 230.98 \\
\hline SEm ( \pm$)$ & 0.12 & 0.10 & 0.72 & 1.05 \\
\hline \multirow[t]{2}{*}{$\mathrm{CD}(\mathrm{P}=\mathbf{0 . 0 5})$} & NS & 0.61 & NS & 6.43 \\
\hline & & Variety (V) & & \\
\hline$V_{1}$ & 8.70 & 5.47 & 54.55 & 296.89 \\
\hline $\mathbf{V}_{2}$ & 8.90 & 4.47 & 47.11 & 209.88 \\
\hline $\mathbf{V}_{3}$ & 9.10 & 4.55 & 54.14 & 245.90 \\
\hline SEm $( \pm)$ & 0.12 & 0.13 & 0.41 & 1.12 \\
\hline \multirow[t]{2}{*}{$\mathrm{CD}(\mathrm{P}=0.05)$} & NS & 0.42 & 1.36 & 3.64 \\
\hline & & Fertilizer $(\mathrm{F})$ & & \\
\hline $\mathbf{F}_{1}$ & 8.90 & 5.08 & 51.68 & 263.30 \\
\hline $\mathbf{F}_{2}$ & 8.70 & 4.57 & 52.18 & 238.48 \\
\hline $\operatorname{SEm}( \pm)$ & 0.12 & 0.13 & 0.25 & 1.18 \\
\hline $\mathrm{CD}(\mathrm{P}=0.05)$ & NS & NS & NS & 7.20 \\
\hline
\end{tabular}

$*$ Where $D_{1}$ and $D_{2}$ represent Date of sowing, $18^{\text {th }}$ November and $28^{\text {th }}$ November respectively, $V_{1}, V_{2}$ and $V_{3}$ represent varieties, Kufri Pukhraj, Kufri Chandramukhi, Kufri Jyoti respectively and $F_{1}$ and $F_{2}$ represent 200:150:150 and 150:125:125 kg/ha of N: $\mathrm{P}_{2} \mathrm{O}_{5}: \mathrm{K}_{2} \mathrm{O}$ respectively.

\begin{tabular}{|c|c|c|c|c|}
\hline \multicolumn{5}{|c|}{ Table.2 Effect of date of sowing, variety and fertilizer on tuber yield $\left(\mathrm{t} \mathrm{ha}^{-1}\right)$ of potato } \\
\hline Treatments & $\begin{array}{c}\text { Small } \\
(0-25 \mathrm{~g})\end{array}$ & $\begin{array}{l}\text { Medium } \\
(26-75 \mathrm{~g})\end{array}$ & $\begin{array}{c}\text { Large } \\
\text { (more than75 g) }\end{array}$ & Total yield \\
\hline & & Date of sowing (D) & & \\
\hline $\mathbf{D}_{1}$ & 2.16 & 21.51 & 3.93 & 27.60 \\
\hline $\mathbf{D}_{2}$ & 2.01 & 19.67 & 3.47 & 25.15 \\
\hline $\operatorname{SEm}( \pm)$ & 0.08 & 0.40 & 0.18 & 1.19 \\
\hline \multirow[t]{2}{*}{$\mathbf{C D}(\mathbf{P}=\mathbf{0 . 0 5})$} & NS & NS & NS & NS \\
\hline & & Variety (V) & & \\
\hline$V_{1}$ & 2.14 & 22.19 & 5.47 & 29.80 \\
\hline$V_{2}$ & 2.24 & 20.16 & 2.59 & 24.99 \\
\hline $\mathbf{V}_{3}$ & 1.91 & 19.38 & 3.05 & 24.34 \\
\hline $\operatorname{SEm}( \pm)$ & 0.15 & 0.62 & 0.22 & 0.46 \\
\hline \multirow{2}{*}{$\mathrm{CD}(\mathrm{P}=0.05)$} & NS & NS & 0.72 & 1.49 \\
\hline & & Fertilizer $(\mathrm{F})$ & & \\
\hline$F_{1}$ & 1.17 & 16.14 & 3.06 & 27.79 \\
\hline$F_{2}$ & 1.00 & 14.25 & 2.34 & 24.97 \\
\hline $\operatorname{SEm}( \pm)$ & 0.07 & 0.09 & 0.23 & 0.48 \\
\hline $\mathrm{CD}(\mathrm{P}=0.05)$ & NS & 0.59 & NS & 2.89 \\
\hline
\end{tabular}

*Where $\mathrm{D}_{1}$ and $\mathrm{D}_{2}$ represent Date of sowing, $18^{\text {th }}$ November and $28^{\text {th }}$ November respectively, $\mathrm{V}_{1}, \mathrm{~V}_{2}$ and $\mathrm{V}_{3}$ represent varieties, Kufri Pukhraj, Kufri Chandramukhi, Kufri Jyoti respectively and $\mathrm{F}_{1}$ and $\mathrm{F}_{2}$ represent 200:150:150 and 150:125:125 kg/ha of $\mathrm{N}: \mathrm{P}_{2} \mathrm{O}_{5}: \mathrm{K}_{2} \mathrm{O}$ respectively. 


\begin{tabular}{|c|c|c|c|c|c|c|}
\hline \multicolumn{2}{|c|}{ Table.3 Effect of date of sowing, variety and fertilizer doses on available N, P and K in soil after harvesting of } \\
potato \\
\hline \multirow{2}{*}{ Treatments } & \multicolumn{2}{|c|}{$\begin{array}{c}\text { Available } \mathrm{N}\left(\mathrm{kg} \mathrm{ha}^{-1}\right) \\
\end{array}$} & Available $\mathrm{P}\left(\mathrm{kg} \mathrm{ha}^{-1}\right)$ & \multicolumn{2}{c|}{ Available K $\left(\mathrm{kg} \mathrm{ha}{ }^{-1}\right)$} \\
\hline & Initial & Final & Initial & Final & Initial & Final \\
\hline $\mathbf{D}_{\mathbf{1}} \mathbf{V}_{\mathbf{1}} \mathbf{F}_{\mathbf{1}}$ & 207.65 & 235.11 & 17.75 & 23.15 & 208.59 & 230.11 \\
\hline $\mathbf{D}_{\mathbf{1}} \mathbf{V}_{\mathbf{1}} \mathbf{F}_{\mathbf{2}}$ & 207.65 & 218.31 & 17.75 & 20.80 & 208.59 & 224.52 \\
\hline $\mathbf{D}_{\mathbf{1}} \mathbf{V}_{\mathbf{2}} \mathbf{F}_{\mathbf{1}}$ & 207.65 & 231.16 & 17.75 & 24.11 & 208.59 & 233.41 \\
\hline $\mathbf{D}_{\mathbf{1}} \mathbf{V}_{\mathbf{2}} \mathbf{F}_{\mathbf{2}}$ & 207.65 & 220.33 & 17.75 & 21.00 & 208.59 & 229.62 \\
\hline $\mathbf{D}_{\mathbf{1}} \mathbf{V}_{\mathbf{3}} \mathbf{F}_{\mathbf{1}}$ & 207.65 & 229.21 & 17.75 & 25.05 & 208.59 & 240.51 \\
\hline $\mathbf{D}_{\mathbf{1}} \mathbf{V}_{\mathbf{3}} \mathbf{F}_{\mathbf{2}}$ & 207.65 & 218.51 & 17.75 & 20.11 & 208.59 & 230.62 \\
\hline $\mathbf{D}_{\mathbf{2}} \mathbf{V}_{\mathbf{1}} \mathbf{F}_{\mathbf{1}}$ & 207.65 & 230.51 & 17.75 & 26.05 & 208.59 & 228.21 \\
\hline $\mathbf{D}_{\mathbf{2}} \mathbf{V}_{\mathbf{1}} \mathbf{F}_{\mathbf{2}}$ & 207.65 & 220.21 & 17.75 & 22.51 & 208.59 & 221.56 \\
\hline $\mathbf{D}_{\mathbf{2}} \mathbf{V}_{\mathbf{2}} \mathbf{F}_{\mathbf{1}}$ & 207.65 & 236.22 & 17.75 & 26.73 & 208.59 & 236.11 \\
\hline $\mathbf{D}_{\mathbf{2}} \mathbf{V}_{\mathbf{2}} \mathbf{F}_{\mathbf{2}}$ & 207.65 & 224.05 & 17.75 & 20.03 & 208.59 & 228.52 \\
\hline $\mathbf{D}_{\mathbf{2}} \mathbf{V}_{\mathbf{3}} \mathbf{F}_{\mathbf{1}}$ & 207.65 & 238.11 & 17.75 & 27.11 & 208.59 & 238.66 \\
\hline $\mathbf{D}_{\mathbf{2}} \mathbf{V}_{\mathbf{3}} \mathbf{F}_{\mathbf{2}}$ & 207.65 & 226.81 & 17.75 & 21.80 & 208.59 & 229.54 \\
\hline
\end{tabular}

*Where $\mathrm{D}_{1}$ and $\mathrm{D}_{2}$ represent Date of sowing, $18^{\text {th }}$ November and $28^{\text {th }}$ November respectively, $\mathrm{V}_{1}, \mathrm{~V}_{2}$ and $\mathrm{V}_{3}$ represent varieties, Kufri Pukhraj, Kufri Chandramukhi, Kufri Jyoti respectively and $\mathrm{F}_{1}$ and $\mathrm{F}_{2}$ represent 200:150:150 and 150:125:125 kg/ha of $\mathrm{N}_{2} \mathrm{P}_{2} \mathrm{O}_{5}: \mathrm{K}_{2} \mathrm{O}$, respectively.

\begin{tabular}{|c|c|c|c|}
\hline \multicolumn{4}{|c|}{$\begin{array}{l}\text { Table.4 Effect of treatments on pod yield }\left(\mathrm{kg} \mathrm{ha}^{-1}\right) \text {, haulm yield }\left(\mathrm{kg} \mathrm{ha}^{-1}\right) \text { and kernel yield }\left(\mathrm{kg} \mathrm{ha}^{-1}\right) 0 \\
\text { groundnut }\end{array}$} \\
\hline Treatment & $\begin{array}{l}\text { Pod yield } \\
\left.\mathrm{ha}^{-1}\right)\end{array} \quad(\mathrm{kg}$ & $\begin{array}{l}\text { Haulm yield } \\
\left(\mathrm{kg} \mathrm{ha}^{-1}\right)\end{array}$ & $\begin{array}{l}\text { Kernel yield } \\
\left(\mathrm{kg} \mathrm{ha}^{-1}\right)\end{array}$ \\
\hline & \multicolumn{2}{|c|}{ Date of sowing (D) } & \\
\hline$D_{1}$ & 2667 & 3285 & 1900 \\
\hline $\mathbf{D}_{2}$ & 2416 & 3073 & 1696 \\
\hline $\operatorname{SEm}( \pm)$ & 53.470 & 17.000 & 12.500 \\
\hline \multirow[t]{2}{*}{$\mathrm{CD}(\mathrm{P}=\mathbf{0 . 0 5})$} & NS & 103.443 & 76.061 \\
\hline & \multicolumn{2}{|c|}{ Variety (V) } & \\
\hline $\mathrm{V}_{1}$ & 2595 & 3216 & 1830 \\
\hline $\mathbf{V}_{2}$ & 2514 & 3165 & 1794 \\
\hline $\mathbf{V}_{3}$ & 2515 & 3156 & 1771 \\
\hline $\operatorname{SEm}( \pm)$ & 41.20 & 32.90 & 27.30 \\
\hline \multirow[t]{2}{*}{$\mathrm{CD}(\mathrm{P}=\mathbf{0 . 0 5})$} & NS & 107.29 & NS \\
\hline & \multicolumn{2}{|c|}{ Fertilizer $(\mathrm{F})$} & \\
\hline$F_{1}$ & 2604 & 3233 & 1850 \\
\hline $\mathbf{F}_{2}$ & 2479 & 3125 & 1747 \\
\hline $\operatorname{SEm}( \pm)$ & 5.90 & 18.80 & 18.20 \\
\hline \multirow[t]{2}{*}{$\mathrm{CD}(\mathrm{P}=\mathbf{0 . 0 5})$} & 35.90 & 114.39 & 110.74 \\
\hline & \multicolumn{2}{|c|}{ Fertilizer (FG) } & \\
\hline $\mathbf{F G}_{1}$ & 2367 & 2928 & 1632 \\
\hline $\mathbf{F G}_{2}$ & 2632 & 3243 & 1873 \\
\hline $\mathrm{FG}_{3}$ & 2683 & 3322 & 1941 \\
\hline $\mathbf{F G}_{4}$ & 2486 & 3223 & 1747 \\
\hline $\operatorname{SEm}( \pm)$ & 19.90 & 41.50 & 32.40 \\
\hline $\mathrm{CD}(\mathrm{P}=\mathbf{0 . 0 5})$ & 68.86 & 143.60 & 112.11 \\
\hline
\end{tabular}

*Where $\mathrm{D}_{1}$ and $\mathrm{D}_{2}$ represent Date of sowing, $18^{\text {th }}$ November and $28^{\text {th }}$ November respectively, $\mathrm{V}_{1}, \mathrm{~V}_{2}$ and $\mathrm{V}_{3}$ represent varieties, Kufri Pukhraj, Kufri Chandramukhi, Kufri Jyoti respectively, $F_{1}$ and $F_{2}$ represent 200:150:150 and 150:125:125 kg/ha of $\mathrm{N}: \mathrm{P}_{2} \mathrm{O}_{5}: \mathrm{K}_{2} \mathrm{O}$ respectively in potato and $\mathrm{FG}_{1,}, \mathrm{FG}_{2}, \mathrm{FG}_{3}$, and $\mathrm{FG}_{4}$ represent No fertilizer, 25 $\%$ of RDF, $50 \%$ of RDF, $75 \%$ of RDF respectively in groundnut. 


\section{Haulm yield ( $\left.\mathrm{kg} \mathrm{ha}^{-1}\right)$}

Date of sowing of preceding crop potato had significant influence in the haulm yield of groundnut. The highest haulm yield was recorded with the treatment $D_{1}\left(3285 \mathrm{~kg} \mathrm{ha}^{-1}\right)$. Due to varietal treatment also haulm yield was significantly differed and the maximum haulm yield was recorded in variety $\mathrm{V}_{1}$ (3216 $\left.\mathrm{kg} \mathrm{ha}{ }^{-1}\right)$. Fertilizer treatment also produced significant effect on haulm yield and it was obtained with the treatment $F_{1}\left(3233 \mathrm{~kg} \mathrm{ha}^{-1}\right)$

\section{Kernel yield $\left(\mathrm{kg} \mathrm{ha}^{-1}\right)$}

Significant variation due to date of sowing of preceding crop potato was observed on kernel yield. The highest Kernel yield was recorded with the treatment $D_{1}\left(1900 \mathrm{~kg} \mathrm{ha}^{-1}\right)$. However there is no significant effect on kernel yield of groundnut due to varietal treatment. There was also a significant effect due to fertilizer treatment. The highest kernel yield was obtained with the treatment $F_{1}\left(1850 \mathrm{~kg} \mathrm{ha}^{-1}\right)$.

\section{Effect due to fertilizer doses in groundnut}

The fertilizer doses applied in groundnut after harvest of potato had a profound effect in increasing the groundnut yield. Among four fertilizer doses applied in groundnut the pod yield increased with the increasing levels of fertilizer. Maximum pod yield $\left(2683 \mathrm{~kg} \mathrm{ha}^{-1}\right)$, haulm yield (3322 $\mathrm{kg} \mathrm{ha}^{-1}$ ) and kernel yield $\left(1941 \mathrm{~kg} \mathrm{ha}^{-1}\right.$ ) were obtained in $\mathrm{FG}_{3}$ treatment (50\% of RDF applied in groundnut) thereafter yield decreased with further increased the fertilizer level in the treatment $\mathrm{FG}_{4}(75 \%$ of RDF applied in groundnut). This might be due to the residual NPK fertilizer which was present in the soil in considerable amount. The treatment $\mathrm{FG}_{3}$ and $\mathrm{FG}_{2} \quad(75 \%$ and $25 \%$ of $\mathrm{RDF}$ in groundnut) was statistically at par but significantly differed from $\mathrm{FG}_{1}$ (no fertilizer in groundnut) and $\mathrm{FG}_{4}$ (75\% of RDF applied in groundnut).

It can be concluded that good harvest of the potato tuber can be obtained with $18^{\text {th }}$ November sowing using Kufri Pukhraj variety with a fertilizer dose of 200: 150:150 kg ha ${ }^{-1}$ of $\mathrm{N}$ : $\mathrm{P}_{2} \mathrm{O}_{5}$ and $\mathrm{K}_{2} \mathrm{O}$. From this experiment it may be concluded that potato planting in right time with optimum dose of fertilizer not only produced the highest tuber yield but also a good harvest of the succeeding crop like groundnut could be achieved with reducing dose $(50 \%$ of recommended dose) of fertilizer. Thus, higher profit is possible under such productive cropping sequence.

\section{References}

Mehdi, M., Saleem, T., Rai, H.K., Mir, M.S. and Rai, G. (2008). Effect of Nitrogen and FYM interaction on yield and yield traits of potato genotypes under ladakh Condition. Potato Journal. 35 (3-4):126129.

Lanker, G.M., Ghulam-ud-Din and Wani, G.A.. (2000). Potato yield and nutrient uptake as influenced by different levels of Nitrogen. SKUAST J. Res. 2:58-61.

Patel R.N., Shah, D.S., Patel N.H., Kanbi, V.H., Paul Khurana S.M. and Pandey, S.K.. (2002). Yield Performance and Adaptability of Different Potato Varieties in Gujarat. Potato Journal. 29 (1-2): 51-54.

Sasani,G.V., Patel, C.K., Patel, N.H. and Patel, R.N. (2002). Fertilizer management in potato-bajra-groundnut and potatogroundnut-til cropping systems under North Gujarat conditions. Journal of Indian Potato Assoc. 29 (3/4): 139-14.

\section{How to cite this article:}

Gangarani Devi, Th., and Sunil Kumar Gunri. 2019. Response of Potato as Influenced by Date of Sowing, Variety and Fertilizer Dose and its Influence on Succeeding Groundnut Crop. Int.J.Curr.Microbiol.App.Sci. 8(11): 2375-2380. doi: https://doi.org/10.20546/ijcmas.2019.811.275 